December 2010

\title{
Reconciliation and Justice after Genocide: A Theoretical Exploration
}

Geneviève Parent

Follow this and additional works at: https://digitalcommons.usf.edu/gsp

\section{Recommended Citation}

Parent, Geneviève (2010) "Reconciliation and Justice after Genocide: A Theoretical Exploration," Genocide Studies and Prevention: An International Journal: Vol. 5: Iss. 3: Article 5.

Available at: https://digitalcommons.usf.edu/gsp/vol5/iss3/5

This Articles is brought to you for free and open access by the Open Access Journals at Digital Commons @ University of South Florida. It has been accepted for inclusion in Genocide Studies and Prevention: An International Journal by an authorized editor of Digital Commons @ University of South Florida. For more information, please contact digitalcommons@usf.edu. 


\title{
Reconciliation and Justice after Genocide: A Theoretical Exploration
}

\author{
Geneviève Parent \\ Laurentian University
}

This article argues that the post-conflict reconciliation process is undermined by the importance given to the retributive form of justice dominating peacebuilding and transitional justice measures. Retributive justice reinforces the division between perpetrator and victim, thus undermining the reconciliation process between antagonistic parties. The so-called objective categories of perpetrator and victim, so crucial for the administration and management of most peacebuilding measures, underestimate the individual and collective psychological dimension and intersubjective effects that these categories have upon the healing and reconciliation processes. The significance of the psychological dimension of reconciliation suggests a restorative justice approach that emphasizes the subjective and intersubjective meanings of justice and reconciliation. The case of post-genocide Rwanda will be used to show how the retributive justice approach can undermine the reconciliation process.

Key words: reconciliation, genocide, restorative justice, retributive justice, psychological healing

Transitional justice refers to a number of peacebuilding measures that are internationally, nationally, and/or locally rooted, such as international tribunals, amnesties, truth commissions, criminal trials, reparation programs, and memorials. Despite these various efforts and despite the growing body of literature on transitional justice, it remains unclear if and how these activities contribute to post-conflict reconciliation processes. This article seeks to contribute to the discussion through an interdisciplinary reading of the relationship between the form of justice being administered and post-conflict reconciliation, notably through an exploration of the significance of the psychological dimension in post-conflict societies.

The article begins by discussing reconciliation, and how the concept relates crucially to the concept of justice. In view of the former's function in post-conflict peacebuilding settings, there is a critical need to refine the vague and confusing reconciliation concept and to discuss its relationship to the concept of justice. The increasingly prevailing "retributive" form of justice of contemporary peacebuilding efforts, it is argued, produces an unnecessary paradox or misleading choice between dispensing justice and promoting peace and reconciliation (the famous justice versus peace "dilemma"). A "restorative" form of justice, on the other hand, can promote both justice and reconciliation. It is argued that the rigid and static victim and perpetrator labels not only poorly reflect fluid and changing sets of identities (e.g., victim, defender, caretaker, perpetrator, hero, mother, father) but also lead to increasing animosity between antagonistic groups. The argument presented here thus emphasizes the psychological and intersubjective dimensions of civil war and genocide survivors' experiences that have to be taken into account to guarantee the

Geneviève Parent, "Reconciliation and Justice after Genocide: A Theoretical Exploration," Genocide Studies and Prevention 5, 3 (December 2010): 277-292. (C) 2010 Genocide Studies and Prevention. doi:10.3138/gsp.5.3.277 
success and durability of the reconciliation process. It will also examine the conflictual nature and dynamics of reconciliation so as to underline how reconciliation can be influenced by the form of justice privileged in transitional periods. To ignore these aspects is to seriously jeopardize the medium and long-term prospects of reconciliation processes.

\section{Post-conflict Reconciliation}

How can reconciliation be possible? It is very difficult. I cannot reconcile with the person who killed members of my family. He cannot bring them back, he cannot erase the pain ... Nothing of them (family members) is left. It is as if they never existed. ${ }^{1}$

In spite of extensive interest in post-conflict reconciliation, the concept remains unclear and loosely used by both scholars and political actors. While this ambiguity can serve many social and political purposes, it also leads to a number of assumptions about the links between reconciliation and other crucial concepts, such as justice, forgiveness, truth, healing, peace, and so on. Some argue or simply assume that these concepts are part of reconciliation, ${ }^{2}$ while others question these takenfor-granted relationships. ${ }^{3}$

Despite the need to challenge the assumed relationship between reconciliation and numerous other concepts, a recurrent theme is that reconciliation, somehow, helps people to heal. In fact, healing is a pervasive term in the literature on reconciliation ${ }^{4}$ and the latter is even often confused with healing. ${ }^{5}$ What and who needs to be healed or what kind of healing is necessary for reconciliation to take place is unclear. Some explicitly indicate that post-conflict individual wounds need healing. Nevertheless, a broad understanding includes the healing of social relations. ${ }^{6}$ Some authors also point to the importance of healing individual post-conflict woundsnotably psychological ones-for reconciliation to occur. ${ }^{7}$ Healing seemingly has an influence on reconciliation. The antagonistic parties go through some sort of healing for reconciliation to occur.

There is little agreement beyond (an essentially implicit) healing on what reconciliation really means. Daly and Sarkin highlight the irony that a term that evokes cohesion has so many divergent meanings, sometimes even competing ones, ranging from not killing each other to the equivalent of "a national hug." 8 For example, Ross refers to reconciliation as a continuum where we find different degrees of reconciliation. ${ }^{9}$ Congruent with this continuum, recent literature tends to see reconciliation as a goal and a process. Several authors emphasize the transformative, dynamic, and conflictual aspects of the reconciliation process. ${ }^{10}$ Indeed, reconciliation is not a progressive linear process.

Accordingly, reconciliation is better understood as a societal process where each party is supposed to acknowledge the other and the other's sufferings, where antagonistic parties are to move onto constructive attitudes and behaviors, and/or where individual and collective relationships of trust are (re)built. ${ }^{11}$ This social process, however, entails a significant psychological dimension: "a changed psychological orientation toward the other." 12 More often than not, the members of antagonistic groups must overcome perceptions and feelings of enmity that are often based upon horrific personal experiences and/or upon demonizing and dehumanizing representations of the "other." The psychological challenge, both individual and collective, is double: (1) to overcome the psychological effects of terrible war experiences; and (2) to see the (old) enemy as a fellow human being with whom it is possible to coexist. Hence, in the end, post-conflict reconciliation involves not only trust and constructive 
attitudes or imposed peacebuilding measures, but recognizing the humanity of the "other"; that is, the "other's" needs, interests, understandings, and perceptions of war, peace, and even reconciliation. Reconciliation might be a very complex social process, but it requires more than material reparations and the administration of (retributive) justice. To be effective, it must also include a significant psychological healing dimension that requires transforming the psychological orientation of antagonistic groups and individuals toward each other. As it is argued below, this emphasis on the psychological dimension entails redefining the relationship between reconciliation and (restorative) justice. But first, I must elaborate on the importance of the psychological dimension, notably in the context of a divided society.

\section{Considering the Psychological Dimension in a Divided Society}

Reconciliation is always difficult to achieve in post-conflict societies, and even more so in the context of deeply divided societies fractured by cycles of extreme violence and/or genocide. The one-size-fits-all characteristic of many peacebuilding and transitional justice measures do not make the task of reconciliation easier. Daly and Sarkin suggest that reconciliation measures should be shaped to include three criteria: (1) the general context before the transitional period (the nature of human rights violations, for instance); (2) the nature of the transition (if it took place by force, by negotiation, or otherwise); and (3) the social and political conditions going into the reconciliation process (the victim-perpetrator ratio, socio-economic conditions, and so on). ${ }^{13}$ It seems that, the more extreme the violence and the war crimes, the more emphasis should be put on the psychological dimension for a "successful" reconciliation process. ${ }^{14}$ Also, coerced participation in reconciliation will not lay the ground for one's empowerment. It does not encourage one to assume a sense of responsibility for his/her actions, or to adopt a sense of engagement either. Any imposed reconciliation measure will bring little to no relief on one's post-conflict wounds, or change one's psychological orientation toward the other. Despite the unique experiences of each country, there is growing evidence that a deeply divided society necessitates the prioritization of the psychological dimension. ${ }^{15}$

Some scholars contend that liberal institutions are necessary for durable peace and/or that socio-economic changes are as important for reconciliation as psychological healing. Lipschutz ${ }^{16}$ and Hutchison and Bleiker, ${ }^{17}$ among others, argue that the exclusive restoration of state institutions and of the economy is insufficient to repair the damaged or broken down relationships after years of violence and war. Without the healing of individual wounds and (re)building of relationships between individuals and groups, the capacity and ability of the citizens to participate in development work are hampered, thus, weakening the communities' capacity to fight poverty. This sort of argument and debate reflects the complexity in implementing reconciliation processes.

Reconciliation is made more complex by the question of the level at which reconciliation should take place: local, national, or international. At the level of individuals, the focus is on the experience of the individuals who are or were affected by the armed conflict. The emphasis is, for instance, upon the relationship between individual victims and perpetrators. At the level of the community, peacebuilding reconciliation implies engaging the former enemy groups/communities, involving both internal and intergroup social dynamics. It is, however, at the national level that one finds the bulk of the literature on liberal peacebuilding, state-building, and transitional justice. It is also and mostly at this level that the international community directs its demands for reconciliation. Hence, reconciliation considers the meaning of "peace" 
between government and the rebel group(s), implies adopting and implementing better policies, building "liberal" institutions, and changing the attitudes and behaviors of those in power. ${ }^{18}$ Within this framework, internally displaced persons are often marginalized, although many have warned that they must be considered because they can greatly exacerbate problems and obstruct reconciliation. ${ }^{19}$ Since transitional countries have little resources, the need is to target problems efficiently in order to determine at which level reconciliation programs should be aimed and work best. ${ }^{20}$

The question of the relevant level of reconciliation largely depends on "who is looking at it." In academia for instance, political scientists tend to put more emphasis on the state, ${ }^{21}$ whereas social psychologists tend to focus on individuals and increasingly on social groups. ${ }^{22}$ Although some put forward a multilevel approach, ${ }^{23}$ it is far from a predominant approach to the problem of reconciliation. In practice, the importance of the psychological dimension of reconciliation is much more explicit at the local and social/community levels (e.g., local initiatives, NGOs, etc.), while it tends to be ignored, dismissed, and/or minimized by national and international peacebuilders (e.g., international courts, state/nation-building efforts, etc.). Attention should be paid to this issue because reconciliation is almost always working at all levels simultaneously, but not necessarily harmoniously. Hence, differences in purposes or objectives are reflected in the respective levels, contradicting or working against each other. It is important to have a global perspective on reconciliation where all levels are considered. The variety of different understandings of reconciliation must bring scholars and stakeholders from different fields and perspectives together-examining the affinities and tensions - in order to bridge the division and have a holistic and inclusive approach to reconciliation. This diversity should be an opportunity to engage into dialogue with others-all parts of a whole-to challenge one's own understanding or to explore new understandings rather than to divide each into camps of like-minded individuals in order to strengthen one's own viewpoints. Otherwise, efforts at one or more level(s) could work against other level(s). Processes of reconciliation will or will not foster sustainable peace, but they will transform individuals, communities, groups, and their interrelationships.

To be effective, the reconciliation process must proceed bottom-up and top-down simultaneously. Indeed, individuals are the fundamental elements of society and widespread trauma throughout the population negatively affects all possible levels of reconciliation. ${ }^{24}$ Most importantly, while the physical and mental health of individuals is crucial for national reconciliation, national reconciliation has no immediate, automatic, or necessary effect upon individual well-being. ${ }^{25}$ A government can promote individual reconciliation through "genuine commitment" and "conciliatory acts" done in public, which are accompanied by other initiatives such as funding direct assistance to survivors or supporting public education. In short, citizens have to believe that the government is genuinely seeking reconciliation. In the context of a divided society, the importance of the psychological dimension-extreme traumatization of the citizens-is substantiated by a number of defining features. For instance, a divided society is characterized by the geographic proximity of the antagonistic parties (often living as neighbors); by the perpetuation of conflicts across generations; by the lines of conflicts that are drawn from regional, religious, and/or ethnic affiliations where one group oppressed the other; and by direct violence infliction. ${ }^{26}$ The experience of civil war is thus very different from the experience of interstate war because it often questions and challenges the very nature and/or raison d'être of the society at (civil) war. 
In short, without overlooking socio-economic realities and other "objective" factors, defining reconciliation in terms of (re)building individual relationships and taking into consideration the importance of the psychological dimension of reconciliation-conceived as more subjective in the literature-facilitates the establishment of a basis from which broader social relationships can be (re)built. Especially in the context of a divided society, it is imperative that national reconciliation initiatives resonate and/or concur with lower levels of reconciliation: the social/community and individual levels. As pointed out by Hamber, it has become critical that more attention is given to mental health in post-conflict political pro$\operatorname{cesses}^{27}$ and, as we will see in the upcoming section, in the field of transitional justice.

This argument is reflected in the literature on reconciliation in the social psychology field. Nadler and Schnabel distinguish between instrumental and socioemotional reconciliation. Socio-emotional reconciliation involves a deeper and more complex transformative aspect than instrumental reconciliation. Thereby, each is said to fit best with different contexts. Instrumental reconciliation is better suited to a context of international or interstate conflict where "separated" coexistence is possible. Socio-emotional reconciliation is better adapted to an intranational context or intra-social conflicts ${ }^{28}$ where coexistence seems inescapable (for whatever reason) and where one peaceful single social/national unit seems the key objective of reconciliation. Instrumental reconciliation is oriented toward the present, whereas socio-emotional reconciliation is oriented toward the past and the future. To be more specific, instrumental reconciliation focuses on ongoing repetitive cooperative projects, while socio-emotional reconciliation first focuses on the confrontation of the conflicted past, where both recognition of past wrongdoings and pleading for forgiveness (however defined) will lay a foundation for building future "relationships of interdependence in a single unit."

Instrumental reconciliation has the "advantage" of being based upon "objective" indicators and factors like economic and political institutions. Moreover, the "objective" characteristics of instrumental reconciliation work well with and serve the retributive understanding of justice underpinning contemporary peacebuilding and transitional justice processes well. Socio-emotional reconciliation, grounded in subjective interrelationships, is less amenable and useful to "concrete" national and international peacebuilding practices and policies. However, not only the "subjective" characteristics of socio-emotional reconciliation concur with one's own healing; they lay the groundwork for one's psychological orientation toward the other. The restorative form of justice suits best the subjective and intersubjective needs of a deeply divided society for socio-emotional reconciliation.

Nevertheless, it is not enough to examine and to emphasize the psychological dimension of reconciliation. If this dimension is to be taken seriously, it must come with an appreciation of the relationship between reconciliation and the form of justice that is promoted or sought. Building on an examination of the case of Rwanda, the rest of this article explores the consequences of the retributive form of justice upon reconciliation and how a restorative form of justice coupled with an emphasis on the psychological dimension can better foster peace and reconciliation.

\section{Reconciliation and the Retributive Form of Justice}

There is little agreement about what transitional justice involves. This is understandable because of each country's unique features (social, legal, economical, and political dynamics) and the complexity of (re)building post-conflict societies. ${ }^{29}$ In 
addition, there is a wide range of possibilities and intertwined approaches to reconciliation, justice, and reconstruction.

Justice can be interpreted in numerous ways. ${ }^{30}$ Yet, as used in the peacebuilding literature, justice as transitional justice is a concept often minimally based upon post-conflict survivors' experiences and upon very little input from conflict survivors and victims. Despite numerous attempts and claims to the objective status of justice, justice can be a highly subjective and intersubjective notion that varies according to context, group membership, and/or personal experiences. Justice is not universal. ${ }^{31}$

And yet, in practice, trials have been increasingly favored in transitional societies: "Practioners in the field argue that there is no peace and no reconciliation without punitive justice." 32 Moreover, the Western "universal" focus on retributive justice is often imposed as a post-conflict solution in war-torn societies. ${ }^{33}$ In practice, however, the majority of individuals who have committed mass atrocities have not been held accountable or punished. In the scholarship on transitional justice, it is also assumed or explicitly claimed that retributive justice should be prioritized in societies divided by mass violence. Some will go as far as conceiving justice as obviously retributive and they will assume the relationship between retributive justice and reconciliation as natural and/or logical:

When justice is done, and seen to be done, it provides a catharsis for those physically or psychologically scarred by violations of international humanitarian law. Deepseated resentments-key obstacles to reconciliation-are removed and people on different sides of the divide can feel that a clean slate has been provided for. ${ }^{34}$

This understanding of justice necessarily implies acts of "injustice" or "wrongs" that must be addressed and rectified through a prism of justice. However, retribution is not necessary to initiate a transition process toward stability and peace. ${ }^{35}$ Retributive justice's primary aim is to punish the offender. At best, a victim gets to be considered as an "official victim" and is given an opportunity to testify in a trial, while the administrators, legislators, prosecutors, and judges are the ones who retain the ultimate power to impose (or not) a punishment. In short, retributive justice essentially constitutes "a transaction between the state and the offender." 36 Claims and assumptions about how retributive justice satisfies the needs and interests of victims seem to ignore the bitter realities of a trial process and victims' experiences of that process. Indeed, these claims and assumptions about retributive justice are challenged and recognized as erroneous in the fields of law and criminology. ${ }^{37}$

Here, I am not particularly concerned about how (transitional) justice can be understood and conceived in different cultural contexts, but how a retributive form of justice can affect reconciliation, notably in terms of the individual psychology of victims of war.

\section{Rwanda}

Three levels of transitional justice can be been identified in Rwanda: the International Criminal Tribunal for Rwanda (ICTR), the formal criminal trials at the national level, and the gacaca courts at the local level.38 After the genocide, the government of Rwanda and the international community put much emphasis on holding perpetrators accountable. Fighting impunity was at the core of the Rwandan government's policies, in conjunction with other measures to promote national reconciliation.

In the context of a post-conflict divided society, within the retributive form of justice framework, the concepts of victim and perpetrator tend to be conceived in 
dichotomous terms: creating two distinct, mutually exclusive, and homogeneous social groups. Victims are conceived as the passive objects of direct violence that become visible only when perpetrators use that violence against them. In some cases, the dichotomy has crucial political effects by generating two social groups that are diametrically opposed, thus simplifying the process of identification of who is the victim and who is the aggressor/perpetrator. This oversimplification is disconnected from the reality of many post-conflict situations, does not reflect the complexity of victimization during conflict, and often defines individual identities as solely that of victim or perpetrator. ${ }^{39}$ Following the harmful act, the victim not only faces numerous consequences and needs, but he/she can ultimately lose control of his/her life. Retributive justice processes depend on the perpetrator to proceed: no perpetrator means no criminal justice process. Moreover, in the event where a monetary compensation for the victim might be considered, the insolvability of the perpetrator leaves the victim with little to no monetary aid to cope with his/her postvictimization consequences and needs. Hence, the victim's loss of control over his/ her life is perpetuated through the retributive justice system's dependency on the perpetrator. ${ }^{40}$ Retributive justice processes are adversarial, and both victims and perpetrators are victimized through them. The victim and perpetrator categories are established, reinforced, and polarized via an increased victimhood of both sides brought about by the system's adversarial procedures.

In the case of Rwanda, there is growing acknowledgment that reconciliation requires more than the prosecutions of the key génocidaires by international and national courts. The international community put great faith into gacaca-encouraging confessions, denunciations, and plea bargaining-for encouraging individual and social reconciliation at least. ${ }^{41}$ However, in Rwanda, gacaca was "adapted" and it seems to have become essentially a retributive tool to punish Hutu. ${ }^{42}$ Waldof even suggests that gacaca might represent a social control tool for the government. The author explains that gacaca, by facilitating mass accusations of Hutu men, not only promotes a collective Hutu guilt, but it can also be used to disenfranchise a significant number of Hutu voters. ${ }^{43}$ As such, this "tool" does not seem to meet the victims' expectations, making them hesitant about any form of reconciliation. ${ }^{44}$ The following testimonies are common:

I have gotten to know many (men) without my consent.... I discovered I am HIV positive. I live in very bad conditions because I didn't go to school (because of the genocide). I have no job and am too weak now to dig the fields. I get food from an organization that helps me to survive.... I don't think I can forgive the FAR soldiers or the Interahamwe. I don't want to hear about reconciliation. I accused them in the gacaca courts, including the one who raped me, those who participated in the killings in the church and those I saw at the roadblock, but now they are being released. Gacaca courts do not bring justice ...

I don't go to the gacaca courts anymore, because the people we are accusing are being released. I don't see the point in taking the risk of sharing my testimony there if it doesn't make any difference ...

I feel the Interahamwe militia and FAR soldiers killed what I would have become. I am HIV positive. I am not able to work, because I am very weak and constantly ill. I suffer from headaches, chest aches, backaches, and pains in my vagina, and I have sinus problems as a result of the men who raped me in the nose ... Some of the Interahamwe militiamen who raped me were imprisoned, but they are now being released. This is not justice. Gacaca courts were supposed to bring justice and reconciliation, but they are bringing more tears than smiles. ${ }^{45}$ 
While in Rwanda silence remains on the alleged RPF war crimes, the number of Hutu suspected of being génocidaires keeps on increasing. ${ }^{46}$ Gacaca played an important role in the staggering increased number of accused génocidaires. ${ }^{47}$ It appears to encourage an "exclusive" form of justice rather than an "inclusive" form where all parties recognize their deeds and the others' sufferings, even if they are of different nature and degree. In fact, increasing literature indicates that the gacaca courts seem to be skewed against Hutu. For instance, the Rwandan ambassador to Belgium indicated that the number of suspected génocidaires was close to two million, which approximated the number of Hutu male in that period. ${ }^{48}$ As Mamdani wrote,

Every time I visited post-genocide Rwanda, I would ask responsible state officials ... how many ordinary civilians they thought had participated in the genocide. Every time the answer was in the millions. Even more troubling, the estimate grew with each visit. ${ }^{49}$

Participation at gacaca courts is mandatory. Despite the much projected image of unanimous Rwandan consensus and support for gacaca initiatives-which might have been genuine in the beginning-many Tutsi have become afraid to participate and to testify with reason: a number of Tutsi have been intimidated, physically assaulted, and even killed before or after their participation at gacaca courts. Tutsi are more insecure since they are often harassed by the families of the individual who killed their relatives. This trend has clearly augmented since 2003, when the first waves of perpetrators/génocidaires were released. Hutu are also afraid of the gacaca courts since they fear being wrongly accused and/or imprisoned. ${ }^{50}$

Furthermore, while the number of guilty has been growing, an increasing number of Rwandans find it more difficult to be recognized as victims since the genocide. The Hutu who resisted during the genocide, who tried to save or saved Tutsi relatives, friends, or neighbors, are not recognized as victims or survivors, while the government tends to naturally label them as génocidaires or accomplices. Many Hutu were also hunted and killed following the genocide by RPF and the Rwandan Patriotic Army. Others died in overcrowded refugee camps in the Democratic Republic of Congo (DRC). ${ }^{51}$ The "mixed" Rwandans also do not appear to meet the criteria of victim. For instance, having one Tutsi parent and one Hutu parent seems to encourage feelings of suspicion about one's involvement in the genocide, whether as a passive accomplice or as an active killer agent. ${ }^{52}$ Tutsi and Hutu live in fear and most are too afraid to talk about the current situation, their experience related to the circumstances that led to their victimization, or to their participation in violence. The official "unity" policy appears to exacerbate the rift between Tutsi and Hutu.

Since the 2003 constitution, the use of the words Hutu, Tutsi, and Twa is illegal in public discourse and is punishable by law. However, despite the fact that the identities are officially silenced, the stigmatization and marginalization associated with them remain and are flourishing. This is largely explained by the fact that the ethnic identities Tutsi and Hutu have become associated with the identities of victim and perpetrator/génocidaire, respectively:

In Rwanda, a Hutu is a perpetrator and a Tutsi is a victim. Because I am Hutu, I am unable to go back to Rwanda to find out who killed my family and why. I cannot see the house, nothing. Without any answer, it is impossible for me to get closure. I suffer great pain. ${ }^{53}$ 
Vidal suggests that the ban on public references to ethnic identity facilitates the link between Hutu and génocidaire since it leads all to forget that Hutu are not all guilty and that some were in fact courageous and/or victimized. ${ }^{54}$ Also, it has been much more difficult to remember and recognize that many Hutu suffered and are suffering since the word Hutu is publicly banned. Hintjens explains that the "victims" in Rwanda-whether they were in exile or in Rwanda-are connected by "a common persecution and their victimizers, as a whole, are to blame" for it. ${ }^{55}$ The dichotomy Tutsi/Hutu is very palpable and perpetuating. The Tutsi constitute an "us"; the Hutu represent the "other." Twa remain invisible/non-existent. Dichotomous identities are implicitly intertwined with the victim/perpetrator dualism, making both dichotomies mutually reinforcing. Both dichotomies have been enforced by Rwandan political programs and initiatives such as the imposition of an official one-sided and exclusive memory.

The question of historical memory, both individual and collective, is crucial to the victim's psychological rehabilitation, and thus to the reconciliation process. And yet each commemoration does not recognize explicitly the massacred Hutu, thus reinforcing the Hutu's collective guilt. Buckley-Zistel contends that each commemoration appears to further create negative emotions and negative cognitive perceptions for both Tutsi and Hutu. ${ }^{56}$ For Tutsi, being reminded of the genocide through commemoration on a daily basis can only feed his/her trauma symptoms, fears, and negative feelings and perceptions toward the "other." Moreover, the impoverished conditions of many Tutsi survivors make matters worse as they claim that the government largely ignores their call for compensation, increasing further their post-conflict difficulties. A number of studies indicate that these material conditions encourage the use of violence in order to remedy the miserable survival conditions. ${ }^{57}$ For Hutu, being identified as accomplices or suspected génocidaires, receiving no acknowledgment for their sufferings and/or good deeds, and being marginalized and stigmatized (often worsening their material conditions) in addition to their post-conflict and post-genocide trauma symptoms (even if they are different than the Tutsi's) produces increasing resentment toward Tutsi. In these conditions where psychological dispositions toward thinking in dualisms are reinforced, the potential to resort to violence against the "other" appears to be increasingly likely.

Burkley-Zistel sustains that there is a "pretended" peace in Rwanda that is supported by fear and pragmatism. In terms of pragmatism, the author explains that living in an environment where "all depend on all," means that "survival and prosperity require collaboration." 58 The gap between "us victims" and "them perpetrators" seems to have been continually and silently widened. Hence, this imposed top-down "ethnic identity unity" and "consensus" do little to promote constructive relationships between Tutsi and Hutu. These national initiatives conflict with any form of psychological healing of individuals and communities. As each Rwandan has to suppress his/her own suffering while trying to survive, openness toward the "other" has become unlikely.

This is basic psychology. Survey studies conducted in Northern Ireland indicate that feelings of victimization of one's party and competitive victimhood with the adversary are negatively related to reconciliation. ${ }^{59}$ On the other hand, empathy and perceptions of common identity with the antagonist was positively related to reconciliation: "a full understanding of intergroup conflict requires changing the relationships between the adversaries (e.g., to greater trust and constructive cooperation) and attending to their psychological needs and feelings (e.g., needs for justice and equality, feelings of victimization or guilt)."60 
The "retributive spirit" (against Hutu) of Rwandan reconciliation processes limits contact and open communication between parties, thus not contributing positively to any form of reconciliation and, in fact, moving away from it. The dependence on finding a perpetrator means that justice becomes offender-oriented rather than victim- and/or community-oriented; more retributive than restorative. As the reconciliation initiatives remain focused on the perpetrator, the victim-conceived as a passive agent-is essentially left aside from the reconciliation process and deprived further from much-needed restoration. Victims and even perpetrators see themselves as "victim," and are unable to heal their post-conflict wounds when the separation between them is reinforced and/or imposed. In this context, the ground cannot be laid for one's psychological re-orientation toward the "other": "Unaddressed hurts and injustices will fester and grow, and ultimately undermine the best political or economic reform." 61

\section{A Restorative Justice Approach to Reconciliation}

While impunity or amnesty for perpetrators is rejected among victims of large-scale violent conflicts, victims of various conflicts do not appear to be focused on the perpetrators' punishment. ${ }^{62}$ It has been observed that victims tend to prioritize diverse measures to address the consequences of large-scale violence. ${ }^{63}$ Among those measures we find: the acknowledgment of their injury, the reparation of harms (material and non-material), and the emergence of the truth about what happened.

Pratto and Glasford argue that restorative justice will promote reconciliation better than retributive justice. ${ }^{64}$ In criminology, restorative justice proponents argue that it is better suited to victims' needs since, "as the individual harmed," the victim is a key stakeholder in the "justice process." Being considered as a central stakeholder, the victim has validation for his/her worth as a member of the communitysomething that is often taken away from him/her by the violent act and is rarely (only symbolically, if ever) restored by retributive justice. ${ }^{65}$

A restorative process is necessarily social and psychological. It allows the victim to share his/her experience of victimization and its aftermath and to get an understanding of what happened from the perpetrator's perspective. The victim decides whether to accept offers for reparations or apologies, for instance. Via a restorative approach, in addition to having a better understanding of what happened (psychological dimension), the victim can benefit from practical and material assistance usually direly needed in post-conflict contexts. The victim might be worse off if the perpetrator gets the "justly deserved" punishment. The victim will often feel more depressed, overwhelmed, and/or disempowered because his/her needs have been disregarded, in addition to seeing his/her wishes and expectations being denied. Indeed, as trauma affects the victim in every spheres of his/her life, punishing the perpetrator brings little to no improvement to his/her survival condition.

In addition to a restoration of the victim's sufferings, restorative justice seeks to restore the humanity of the perpetrator and his/her relationship with the victim. As "an agent of the common good," the perpetrator is asked to take responsibility for his/her actions. ${ }^{66}$ By asking "why," the victim gives an opportunity to the perpetrator to become more human, an opening that retributive justice fails to provide. Both parties can come to agree on the victim's restoration. The perpetrator can acknowledge his/her actions and the following consequences to victims and the community; he/she is encouraged to accept responsibility for his/her deeds, face his/ her loved ones and his/her victim(s). When the perpetrators make amends, the end product does not follow the principle of proportionality of retributive justice. The 
objective is aimed toward the victims' needs and interests because restorative justice prioritizes the victim's restoration rather than the perpetrator's punishment. Without leaving the harmful and illegitimate deeds unpunished, restorative justice restores, so to speak, the perpetrator's humanity; he/she can become a functioning and contributing member of the community again.

Focused on the harms done and their redress, restorative justice promotes the separation between the perpetrator's actions and identity. This approach lays the ground for a different perception of the other's behavior than inherent "evilness." A dialogue on the possibilities of change is more likely. In short, acknowledgment and willingness to seek repairs can be a starting point for a broader reconsideration of relationships among individuals, groups, communities, and societies.

It was argued previously that the distinction between victim and perpetrator are muddied in the context of war, ${ }^{67}$ especially in the context of a genocide. ${ }^{68}$ Indeed, genocide implies that whole communities are displaced or destroyed, neighbors turn against neighbors via forced complicity or inbred distrust. The theoretical static victim and perpetrator identities do not reflect the fluid and changing sets of identities of each individual. Of particular importance in this regard, the ethnic group often determines who is constructed as a victim or as a perpetrator, as seen above in the case of Rwanda. A restorative approach to justice allows more fluidity and flexibility in the victim/perpetrator identification since its responses to harmful or criminal behavior seeks, first, to repair the harm done (to individual, community, society), and, second, to address the reactions and the needs of the parties involved, and then to reintegrate the "author of the harmful or criminal deeds" and the "victim" into the community and society. In short, restorative justice emphasizes the intersubjective relationships and their complexity, especially in post-conflict settings. While restorative justice is not as easily implemented as the retributive form, it seems necessary to facilitate the (re)humanization of both parties. It promotes much needed intergroup contacts in order to (re)build wider social relationships within a deeply divided society.

\section{Conclusion: Psychology, Reconciliation, Justice}

This article challenged the improper separation between the "objective" and the "subjective" implicit in peacebuilding and transitional justice measures brought about by the dichotomy victim/perpetrator found in the retributive form of justice. Furthermore, it questioned the long-term effects of policies built upon such separation and polarization.

Transitional justice initiatives can become a tool that further reinforces the dichotomy victim/perpetrator rather than promote Rwandan reconciliation. In Rwanda, gacaca courts are essentially retributive, thus reinforcing the victim/perpetrator dichotomy. The knock-on effect is to further reinforce the exclusiveness of the perpetrator and the divide between the Tutsi and Hutu.

Retributive justice designates who is the victim and who is the perpetrator and largely ignores, in post-conflict situations, the complexity of determining "who did what to whom." Inappropriately and unsubtly labeled and characterized, Tutsi and Hutu have to face added hardships in silence-as each "objective category" is linked to "privileges" (whatever they may be), to stigmatization, and/or marginalization-in addition to their own post-conflict wounds. Further victimized as their sufferings are increasing, it has become more difficult for one to acknowledge the sufferings of the "other," and less likely for one's psychological re-orientation toward the "other" to 
occur. Officially and overtly identified as victim or perpetrator, each antagonist sees their view of the "other" confirmed or strengthened.

There may be no more official Tutsi and Hutu identities, but the victim/ perpetrator-génocidaires identities could be more powerful than the former in perpetuating the violence. The intensified negative emotions and cognitions, fear, dire survival conditions, and so on, all constitute potential contributors to violence and even genocide. The psychological and intersubjective dimensions of the traumatized are clearly ignored in the reconciliation process, thus jeopardizing its prospects. Unless all levels of reconciliation are considered in an inclusive and holistic way, fear, silence, suppressed anger, hate, denial, among other things, will continue to prevail and to work against reconciliation efforts at all levels. Projects and policies of reconciliation and justice will bring durable peace only if they acknowledge and deal with the intersubjective and psychological complexity of post-conflict environments.

\section{Acknowledgments}

I would like to thank Bruno Charbonneau and two anonymous reviewers for their comments and advice in writing this article.

\section{Notes}

1. Interview, victim of Rwanda's genocide, September 2009.

2. Yaacov Bar-Siman-Tov, "Dialectics between Stable Peace and Reconciliation," in From Conflict Resolution to Reconciliation, ed. Yaacov Bar-Siman-Tov (New York: Oxford University Press, 2004).

3. See Harvey M. Weinstein and E. Stover, "Introduction: Conflict, Justice and Reclamation," in My Neighbor, My Enemy: Justice and Community in the Aftermath of Mass Atrocity, ed. Eric Stover and Harvey M. Weinstein (Cambridge: Cambridge University Press, 2004); Erin Daly and Jeremy Sarkin, Reconciliation in Divided Societies: Finding Common Ground (Philadelphia: University of Pennsylvania Press, 2007); Phil Clark, "Establishing a Conceptual Framework: Six Key Transitional Justice Themes," in After Genocide: Transitional Justice, Post-Conflict Reconstruction and Reconciliation in Rwanda and Beyond, ed. Phil Clark and Zachary D. Kaufman (New York: Columbia University Press, 2009).

4. Daly and Sarkin, Reconciliation in Divided Societies.

5. Clark and Kaufman, "After Genocide," in After Genocide, ed. Clark and Kaufman.

6. For instance, see William J. Long and Peter Brecke, War and Reconciliation: Reason and Emotion in Conflict Resolution (Cambridge: MIT Press, 2003).

7. Ervin Staub, "Reconciliation after Genocide, Mass Killing, or Intractable Conflict: Understanding the Roots of Violence, Psychological Recovery and Steps toward a General Theory," Political Psychology 27, no. 6 (2006): 867-94; Chris Cunneen, "Exploring the Relationship between Reparations, the Gross Violation of Human Rights, and Restorative Justice," in Handbook of Restorative Justice: A Global Perspective, ed. Dennis Sullivan and Larry Tifft (New York: Routledge, 2008); Emma Hutchison and Roland Bleiker, "Emotional Reconciliation: Reconstituting Identity and Community after Trauma," European Journal of Social Theory 11, no. 3 (2008): 385-403; Solomon N. Gasana, "Confronting Conflict and Poverty through Trauma Healing: Integrating Peace-Building and Development Processes in Rwanda," in After Genocide, ed. Clark and Kaufman; John Steward, "Only Healing Heals: Concepts and Methods of Psycho-Social Healing in PostGenocide Rwanda," in After Genocide, ed. Clark and Kaufman.

8. Daly and Sarkin, Reconciliation in Divided Societies, 183.

9. Marc H. Ross, "Ritual and the Politics of Reconciliation," in From Conflict Resolution to Reconciliation, ed. Yaacov Bar-Siman-Tov (New York: Oxford University Press, 2004), 200. 
10. Daly and Sarkin, Reconciliation in Divided Societies; Karen Brounéus, "Analyzing Reconciliation: A Structured Method for Measuring National Reconciliation Initiatives," Peace and Conflict: Journal of Peace Psychology 14, no. 3 (2008): 291-313; Clark and Kafuman, "After Genocide"; Brandon Hamber and Grainne Kelly, "Beyond Coexistence: Towards a Working Definition of Reconciliation," in Reconciliation(s): Transitional Justice in Postconflict Societies, ed. Joanna R. Quinn (Montreal: McGill-Queen's University Press, 2009).

11. See Karen Brounéus, Reconciliation: Theory and Practice for Development Cooperation (Sweden: The Swedish International Development Cooperation Agency, 2003), 294; Staub, "Reconciliation after Genocide, Mass Killing, or Intractable Conflict"; Cheril de la Rey, "Reconciliation in Divided Societies," in Peace, Conflict and Violence, ed. Daniel J. Christie, Richard V. Wagner, and Deborah D. Winter (Upper Saddle River, NJ: Prentice Hall, 2001); Louis Kriesberg, "Coexistence and Reconciliation of Communal Conflicts," in The Handbook of Interethnic Coexistence, ed. Eugene Weiner, Alan B. Slifka, and Lan B. Slifka (New York: Continuum, 1998); John P. Lederach, Building Peace: Sustainable Reconciliation in Divided Societies (Washington, DC: United States Institute of Peace Press, 1997); Joanna R. Quinn, "Introduction," in Reconciliation(s), ed. Quinn.

12. Staub, "Reconciliation after Genocide, Mass Killing, or Intractable Conflict," 868.

13. Daly and Sarkin, Reconciliation in Divided Societies.

14. Charles Villa-Vincencio, "Transitional Justice, Restoration, and Prosecution," in Handbook of Restorative Justice, ed. Sullivan and Tifft; Brandon Hamber, Transforming Societies after Political Violence: Truth, Reconciliation, and Mental Health (New York: Springer, 2009).

15. For instance, Lederach, Building Peace; Ervin Staub, "Genocide and Mass Killing: Origins, Prevention, Healing and Reconciliation," Political Psychology 21, no. 2 (2000): 367-82; Ervin Staub, "Preventing Violence and Generating Humane Values: Healing and Reconciliation in Rwanda," International Review of the Red Cross, December, no. 852 (2003): 791-806; Long and Brecke, War and Reconciliation; Herbert C. Kelman, "Reconciliation as Identity Change: A Social-Psychological Perspective," in From Conflict Resolution to Reconciliation, ed. Bar-Siman-Tov; Ifat Maoz, "Social-Cognitive Mechanism in Reconciliation," in From Conflict Resolution to Reconciliation, ed. Bar-Siman-Tov; Judy Barsalou, "Trauma and Transitional Justice in Divided Societies," Special Report no. 135 (Washington, DC: The United States Institute of Peace, 2005); Ervin Staub, Laurie A. Pearlman, and Rezarta Bilali, "Psychological Recovery, Reconciliation and the Prevention of New Violence: An Approach and Its Uses in Rwanda," in Peacebuilding in Traumatized Societies, ed. Barry Hart (Lanham: University Press of America, 2008); Herbert C. Kelman, "Reconciliation from a Social-Psychological Perspective," in The Social Psychology of Intergroup Reconciliation, ed. Arie Nadler, Thomas E. Malloy, and Jeffrey D. Fisher (New York: Oxford University Press, 2008); Gasana, "Confronting Conflict and Poverty through Trauma Healing"; Steward, "Only Healing Heals."

16. Ronnie D. Lipschutz, "Beyond the Neoliberal Peace: From Conflict Resolution to Social Reconciliation," Social Justice: A Journal of Crime, Conflict and World Order 25, no. 4 (1998): 5-19.

17. Hutchison and Bleiker, "Emotional Reconciliation."

18. Karen Brounéus, "Analyzing Reconciliation: A Structured Method for Measuring National Reconciliation Initiatives," Peace and Conflict: Journal of Peace Psychology 14, no. 3 (2008): 291-313.

19. Luc Huyse, "The Process of Reconciliation," in Reconciliation after Violent Conflict: A Handbook, ed. David Bloomfield, Teresa Barnes, and Luc Huyse (Stockholm: International Institute for Democracy and Electoral Assistance, 2003).

20. Daly and Sarkin, Reconciliation in Divided Societies.

21. For instance, Michael Krepon and Amit Sevak, Crisis Intervention, Confidence Building and Reconciliation in South Asia (New York: St. Martin's Press, 1995); Cynthia J. Arnson, Comparative Peace Processes in Latin America (Stanford: Stanford University Press, 
1999); Mark R. Amstutz, "Is Reconciliation Possible after Genocide: The Case of Rwanda," Journal of Church and State 48, (2006): 541-65.

22. For instance, Nadler and Shnabel, "Instrumental and Socioemotional Paths to Intergroup Reconciliation and the Needs-Based Model of Socioemotional Reconciliation"; Walter G. Stephan, "The Road to Reconciliation," in The Social Psychology of Intergroup Reconciliation, ed. Nadler, Malloy, and Fisher.

23. Lederach, Building Peace.

24. See Daniel Bar-Tal and Gemma H. Bennink, "The Nature of Reconciliation as an Outcome and as a Process," in From Conflict Resolution to Reconciliation, ed. Yaacov Bar-Siman-Tov (New York: Oxford University Press, 2004); Yael Danieli, "Essential Elements of Healing after Massive Trauma: Complex Needs Voiced by Victims/Survivors," in Handbook of Restorative Justice, ed. Sullivan and Tifft.

25. Daly and Sarkin, Reconciliation in Divided Societies.

26. See de la Rey, "Reconciliation in Divided Societies"; John P. Lederach, "Beyond Violence: Building Sustainable Peace," in Beyond Violence, ed. Arthur Williamson (Belfast: Community Relations Council, 1995).

27. Hamber, Transforming Societies after Political Violence.

28. Nadler and Shnabel, "Instrumental and Socioemotional Paths to Intergroup Reconciliation and the Needs-Based Model of Socioemotional Reconciliation," 44.

29. Clark, "Establishing a Conceptual Framework: Six Key Transitional Justice Themes."

30. See Harvey M. Weinstein and Eric Stover, "Introduction: Conflict, Justice and Reclamation," in My Neighbor, My Enemy: Justice and Community in the Aftermath of Mass Atrocity, ed. Eric Stover and Harvey M. Weinstein (Cambridge: Cambridge University Press, 2004).

31. Carrie Gustafson, "International Criminal Courts: Some Dissident Views on the Continuation of War by Penal Means," Houston Journal of International Law 21, no. 1 (1998): 51-84.

32. Huyse, "The Process of Reconciliation," 97.

33. Rama Mani, Beyond Retribution: Seeking Justice in the Shadows of War (Boston: Polity Press, 2002); Suren Pillay, "Conclusion," in Peace versus Justice? The Dilemma of Transitional Justice in Africa, ed. Chandra L. Sriram and Suren Pillay (New Zealand: University of KwaZulu-Natal Press, 2009).

34. Kingsley C. Moghalu, "Reconciling Fractured Societies: An African Perspective on the Role of Judicial Prosecutions," in From Sovereign Impunity to International Accountability: The Search of Justice in a World of States, ed. Ramesh C. Thakur and Peter Malcontent (Tokyo: United Nations Press, 2004), 216.

35. Laurel E. Fletcher, Harvey M. Weinstein, and Jamie Rowen, "Context, Timing and the Dynamics of Transitional Justice: A Historical Perspective," Human Rights Quarterly 31 (2009): 163-220.

36. Andrew Ashworth, "Some Doubts about Restorative Justice," Criminal Law Forum 4, no. 2 (1993): 284.

37. Joanna Shapland, “The Victim, the Criminal Justice System and Compensation," British Journal of Criminology 24 (1984): 131-49; Robert Elias, The Politics of Victimization: Victims, Victimology and Human Rights (New York: Oxford University Press, 1986); Leslie Sebba, Third Parties: Victims and the Criminal Justice System (Columbus: Ohio State University Press, 1986); Brian Williams, Working with Victims of Crime: Policies, Politics and Practice (London: Jessica Kingsley Publishers, 1999); Jo Goodey, Victims and Victimology: Research, Policy and Practice, (Harlow: Pearson Education Limited, 2005); William G. Doerner and Steve P. Lab, Victimology, 5th ed. (Cincinnati: Lexis Nexis, 2008).

38. For more details on each initiative, see William A. Schabas, "Post-Genocide Justice in Rwanda: A Spectrum of Options"; Bert Ingelaere, "The Gacaca Courts in Rwanda," in Traditional Justice and Reconciliation after Violent Conflict: Learning from African Experiences, ed. Luc Huyse and Mark Salter (Stockholm: International Institute for 
Democracy and Electoral Assistance, 2008); and Urusaro A. Karekezi, Alphonse Nshimiyimana, and Beth Mutamba, "Localizing Justice: Gacaca Courts in Post-Genocide Rwanda," in My Neighbor, My Enemy, ed. Stover and Weinstein.

39. Erica Bouris, Complex Political Victims (Bloomfield: Kumarian Press, 2007).

40. For instance, for more details concerning some of the victims' hardships related to the possibilities of post-victimization assistance, see Marion E.I. Brienen and Ernestine H. Hoegen, Victims of Crime in 22 European Jurisdictions: The Implementation of Recommendation 85(11) of the Council of Europe on the Position of the Victim in the Framework of Criminal Law and Procedure (Tillburg: Wolf Legal Productions, 2000).

41. Donna Pankhurst, "Issues of Justice and Reconciliation in Complex Political Emergencies: Conceptualizing Reconciliation, Justice and Peace," Third World Quarterly 20, no. 1 (1999): 239-56.

42. There is ample and increasing literature deploring the increasing retributive transformation of the gacaca courts. See, for instance, Rosemary Nagy, "Traditional Justice and Legal Pluralism in Transitional Context: The Case of Rwanda's Gacaca Courts," in Reconciliation(s), ed. Quinn; Alana E. Tiemessen, "After Arusha: Gacaca Justice in PostGenocide Rwanda," African Studies Quarterly 8, no. 1 (2004): 57-76; Eugenia Zorbas, "Reconciliation in Post-Genocide Rwanda," African Journal of Legal Studies 1, no. 1 (2004): 29-52.

43. Lars Waldorf, "Mass Justice for Mass Atrocity: Rethinking Local Justice as Transitional Justice," Temple Law Review 79, no. 1 (2006): 1-87.

44. For instance, see Jean Baptiste Kayigamba, "Without Justice, No Reconciliation: A Survivor's Experience of Genocide," in After Genocide, ed. Clark and Kaufman.

45. In Anne-Marie de Brower and Sandra Chu, The Men Who Killed Me (Vancouver: Douglas and McIntyre, 2009), 33, 56, 76-77.

46. Helen Hintjens, "Post-Genocide Identity Politics in Rwanda," Ethnicities 8, no. 1 (2008): 5-41; René Lemarchand, "Genocide, Memory and Ethnic Reconciliation in Rwanda," in L'Afrique des Grands Lacs, Annuaire 2006-2007, ed. Stefaan Marysse, Filip Reyntjen, and Stef Vandeginste (Belgium: L'Harmattan, 2007).

47. Nagy, "Traditional Justice and Legal Pluralism in Transitional Context: The Case of Rwanda's Gacaca Courts"; Schabas, "Post-Genocide Justice in Rwanda."

48. Nigel Eltringham, Accounting for Horror Post-Genocide Debates in Rwanda (London: Pluto Press, 2004).

49. Mahmood Mamdani, When Victims Become Killers: Colonialism, Nativism, and the Genocide in Rwanda (Princeton: Princeton University Press, 2001), 266.

50. Susanne Buckley-Zistel, "We Are Pretending Peace: Local Memory and the Absence of Social Transformation and Reconciliation in Rwanda," in After Genocide, ed. Clark and Kaufman.

51. Ibid.; Hintjens, "Reconstructing Political Identities in Rwanda"; René Lemarchand, "The Politics of Memory in Post-Genocide Rwanda," in After Genocide, ed. Clark and Kaufman.

52. Hintjens, "Post-Genocide Identity Politics in Rwanda."

53. Interview, victim of Rwanda's genocide, September 2009.

54. Claudine Vidal, "Les commémorations du génocide au Rwanda," Les Temps Modernes 613 (2001): 1-46.

55. Hintjens, "Reconstructing Political Identities in Rwanda," 8.

56. Buckley-Zistel, "We Are Pretending Peace."

57. For instance, see James Waller, Becoming Evil: How Ordinary People Commit Genocide and Mass Killing, 2nd ed. (New York: Oxford University Press, 2007).

58. Buckley-Zistel, “We Are Pretending Peace,” 136.

59. Masi Noor, Rupert Brown, and Garry Prentice, "Prospect for Intergroup Reconciliation: Social-Psychological Predictors of Intergroup Forgiveness and Reparation in Northern Ireland and Chile," in The Social Psychology of Intergroup Reconciliation, ed. Nadler, Malloy, and Fisher. 
60. Arie Nadler, Thomas E. Malloy, and Jeffrey D. Fisher, "Intergroup Reconciliation: Dimensions and Themes," in The Social Psychology of Intergroup Reconciliation, ed. Nadler, Malloy, and Fisher, 4.

61. International Institute for Democracy and Electoral Assistance, Reconciliation after Violent Conflict: Policy Summary (Stockholm: International Institute for Democracy and Electoral Assistance, 2003), 5.

62. For an overview, see Ernesto Kiza, Corene Rathgeber, and Holger-C. Rohne, Victims of War-An Empirical Study on War Victimization and Victim's Attitudes towards Addressing Atrocities (Hamburg, Germany: Hamburger Institut für Socialforshung, 2002).

63. Holger-C. Rohne, "Opportunities and Limits for Applying Restorative Justice in the Context of the Israeli-Palestinian Conflict," in Restoring Justice after Large-Scale Violent Conflicts, ed. Ivo Aertsen, Jana Arsovska, Holger C. Rohne, Marta Valinas, and Kris Vanspauwen (London: Willan Publishing, 2008).

64. Felicia Pratto and Demis E. Glasford, "How Needs Can Motivate Intergroup Reconciliation in the Face of Intergroup Conflict," in The Social Psychology of Intergroup Reconciliation, ed. Nadler, Malloy, and Fisher, 132.

65. Mary Achilles and Howard Zehr, "Restorative Justice for Crime Victims: The Promise and the Challenge," in Gordon Bazemore and Mara Schiff, Restorative Community Justice: Repairing Harm and Transforming Communities (Cincinnati: Anderson Publishing, 2002), 88-91.

66. Charles Villa-Vicencio, “Transitional Justice, Restoration, and Prosecution," in Handbook of Restorative Justice, ed. Dennis Sullivan and Larry Tifft (New York: Routledge, 2008), 393.

67. Uwe Ewald, "Victimization in the Context of War-Some Aspects of a Macro-Victimological Research Project," European Journal of Crime, Criminal Law and Criminal Justice 10, nos. 2-3 (2002): 90-97.

68. Naomi Roth-Arriaza, "Reparations in the Aftermath of Repression and Mass Violence" in My Neighbor, My Enemy, ed. Stover and Weinstein. 